\title{
Understanding the geographies of religion and secularity: on the potentials of a broader exchange between geography and the (post-) secularity debate
}

\author{
Georg Glasze and Thomas M. Schmitt
}

FA University of Erlangen-Nuremberg, Institute of Geography, Wetterkreuz 15, 91058 Erlangen, Germany

Correspondence: Thomas M. Schmitt (thomas.schmitt@fau.de)

Received: 22 December 2017 - Revised: 7 August 2018 - Accepted: 22 August 2018 - Published: 24 October 2018

\begin{abstract}
For a long time, the mainstream of social and cultural geography seems to have implicitly accepted that religion is becoming obsolete and is of little social significance. However, since the 1990s, religion has aroused new interest in the social sciences in general, and to some extent also in social and cultural geography. Against this backdrop, a controversial discussion has started in geography on the relevance of theories of secularisation and the notion of post-secularity, as well as on possible contributions to these debates. The paper introduces the interdisciplinary debate on revisions of theories of secularisation and the promotion of postsecular perspectives, referring, among others, to Jürgen Habermas, Peter Berger, José Casanova, and Talal Asad. In a second step, we argue that an understanding of post-secularity that focuses on the contingency and contextdependent delimitation of the secular and the religious promises to be fruitful for social and cultural geography and can help us to understand the geographies of religion and secularity.
\end{abstract}

\section{Questioning secularisation - a significant debate for geography}

Often related to the notions of post-secularity, post-secular society, or post-secular geographies, an interdisciplinary debate has begun to question the idea of a linearly and globally progressing secularisation of contemporary societies. This discussion of the role of religion in contemporary societies was triggered by empirical observations which suggested that religious practices and discourses do not simply disappear. Besides these empirical arguments for a persistent, or even growing, significance of religion, the post-secularity debate also encompasses more normative discussions on the significance of religious norms for contemporary societies and conceptual discussions that scrutinise the specific configurations of religion and secularity in different historical and geographical contexts.

With very few exceptions (Wunder, 2005; Wilford, 2010), there has been no conceptual discussion of the theories of secularisation within social and cultural geography. The mainstream of the discipline in the second half of the 20th century implicitly accepted the idea of the growing ir- relevance of religious practices and discourses, thus reducing their study within academic geography to a marginalised sub-discipline. Interestingly enough, the post-secularity debate has attracted more interest since the late 2000s. Especially in Great Britain, geographers have used the debate to analyse the ethical potentials of religious groups for tackling social problems in western European cities. We discuss to what extent social and cultural geography may profit from a broader discussion of the theories of secularisation and the post-secularity debate and to what extent the interdisciplinary debate may in turn profit from specific discussions and sensitivities within social and cultural geography. ${ }^{1}$

\footnotetext{
${ }^{1}$ This special issue is related to two conferences that took place in 2015 on the relationship between the post-secularity debate and social and cultural geography: firstly, an interdisciplinary conference held at the FA-University of Erlangen-Nürnberg in June hosted by the Centre for the Anthropology of Religions (Zentralinstitut Anthropologie der Religionen) in cooperation with the Geography of Religion working group (AK Religionsgeographie) of the German Geographical Society (Deutsche Gesellschaft für Geographie) and the Institute of Geography at the F.A University of ErlangenNürnberg; secondly, a panel session at the German Congress of
} 
Our introduction to this special issue on the relevance of the post-secularity debate for social and cultural geography begins with a short presentation of the arguments offered by the most important supporters of the theories of secularisation or the secularisation thesis (Sect. 2$)^{2}$ and subsequently sketches the arguments of authors who question this thesis. We will then give an overview of the different strands of the (post-)secularity debate and propose three different understandings of post-secularity: (1) post-secularism as a normative programme demanding the acceptance of religious voices in the public sphere, (2) post-secularity as the description of a new era where religion is of increasing (or at least stable) social significance, and (3) post-secularity as a new perspective for the social sciences which denaturalises the notion of secularity and the notion of religion and calls for greater sensitivity to context and contingency (Sect. 3). Section 4 shows that the reception of the (post-)secularity debate in social and cultural geography has focused to a large extent on the first two understandings. This reception has led to sharp criticism by some geographers, calling into question the relevance of the whole post-secularity debate. We argue, on the contrary, that an understanding of post-secularity that focuses on the contingency and context-dependent delimitation of the secular and the religious promises to be fruitful for social and cultural geography and can help us to better understand the geographies of religion and secularity. However, in order to illustrate the interdisciplinary broadness and diversity of the debate, we have invited two scholars who are critical of the notion of post-secularity to contribute to this themed issue and have placed their contributions in short "Contributed texts". Christoph Bochinger critically reflects on the post-secularity debate from the perspective of the study of religion and proposes the concept of religious heterogeneity (see Sect. 3 and "Contributed text 1"). Benedikt Korf (a cultural and political geographer; see "Contributed text 2") criticises the notion of post-secularity for

Geography in Berlin in October 2015. We thank the many speakers and discussants at both conferences. In addition to the authors of the articles in this issue, the authors of the contributed texts (Christoph Bochinger and Benedikt Korf) were present at the conference in Erlangen. Our thanks also go to Justin Beaumont, Reinhard Henkel, and Edgar Wunder for their contributions to the conferences and to the three anonymous reviewers for their contribution to a preliminary version of this paper. These very fruitful exchanges have helped us to clarify our own understanding of the potentials and problems of the post-secularity debate, and as a result our position within this debate has become modified since this themed issue was first conceived of in 2015. We also thank Stephan Adler (graphic design) and Ruth Schubert (proof-reading).

${ }^{2}$ It makes sense to differentiate between the complex and somewhat heterogeneous theories of secularisation and the reception of a more simplified secularisation thesis claiming the irreversible "loss of the social significance of religion in modernising societies" (Pickel, 2011:138, translated from the German). We will switch between the two terms depending on the context. All translations by the authors. presupposing the existence of a secular age which is now being challenged by the survival of religion. Referring to the writings of Talal Asad, Benedikt Korf proposes a provincialising of the ideas and practices not only of secularism but also of post-secularism.

\section{The secularisation thesis - competing meanings of secularisation and critical assessment}

The debate on post-secularity is based on various theories of secularisation which can mainly be traced back to Max Weber's sociology of religion (Weber, 1988, orig. 1920) - even if Weber himself hardly ever used the term secularisation (Gabriel, 2008). Among the internationally known sociologists, Peter Berger (1967) was one of the first to reflect systematically on the concept of secularisation in the period following the Second World War. He defines secularisation as "the process by which sectors of society and culture are removed from the domination of religious institutions and symbols" (Berger, 1967:107). The discursive and institutional authority of religion declined following the rise of the empirical sciences and their specific claims to truth and validity, with the gradual ending of pressure to provide religious legitimation for political power, and in the wake of industrialisation and bureaucratisation. ${ }^{3}$ According to Gabriel (2008), Weber (1988) did not limit "secularisation, as rationalisation of the world, ... to the place of its first breakthrough in western Europe. He cannot conceive of any other possibility than that its triumphal progress around the world started in Europe."4 However, the disenchantment of the world, which was the result of rationalisation (which can be traced back to the monotheism of early Judaism and, later, to medieval scholastic debates) and modernisation, was not a pure Western success story for Weber but at least to an equal extent a story of loss, since neither capitalism nor science nor bureaucratic rule could fill the resulting void in the way people interpret and give meaning to their lives (see Müller, 2007:256).

In more recent debates, different dimensions or levels of meaning of secularisation, in various concrete forms, have been distinguished (see Casanova, 1994, 2015; Taylor, 2007; Barbieri, 2015), which in part can be explicitly traced back to Berger (1967) and at least implicitly to Weber. Our own variant, which we will present here, is based on a triadic conception of the social, i.e. its institutional, discursive, and subjective dimensions, the latter including individual and collective practices but also subjective experiences and convictions (see Schmitt, 2015:10):

\footnotetext{
${ }^{3}$ This also reduced the pressure on individuals, in terms of social desirability, to participate in religious practices.

${ }^{4}$ Original Text: "Säkularisierung als Rationalisierung der Welt [ist] nicht auf den Ort ihres ersten Durchbruchs im westlichen Europa beschränkt. Es ist für ihn nicht anders denkbar, als dass sie von Europa aus ihren Siegeszug über die ganze Welt antritt."
} 
- Secularisation has an institutional and organisational dimension, which, in the course of the functional differentiation of modern societies, affects their macrostructures. The influence of the values and norms of churches and religious communities on other social spheres such as politics, economics, education, science, or art has continuously declined; these spheres have emancipated themselves from the religious sphere (Casanova, 2015:18-19).

- The rise of modern science and technology, as well as empirical social science and the emancipation of philosophy from theology, led to a decline in public respect for the claims to truth and validity of religions and theologies: this concerns the discursive dimension of secularisation. Thus, especially since the European Enlightenment, there has been increasing acknowledgement of positions having no religious legitimation.

- In addition to its institutional and discursive dimensions, secularisation also has a subjective side (Berger, 1967:107) - an individual dimension relating to practices, which manifests itself "in the falling off of religious belief and practice, in people turning away from God, and no longer going to Church" (Taylor, 2007:3; this corresponds to both Taylor's (2007:3) and Casanova's (1994, 2015:19) second dimension of secularisation). It involves (a) a decline in religious beliefs among individuals and (b) a decline in individual participation in religious practices, such as church services. And indeed, in respect of European societies - but not the United States or many other parts of the world - a large number of empirical studies have shown a long-term decline in religious attitudes, church attendance, or church membership (see Fig. 1; on Germany, see for instance Mahne-Bieder and Hilpert, 2016). At least in some parts of the world, it seems that the experience of secularity, of living in a world without religion, has become the normal, quasi-natural case (Casanova, 2015:17); this is also a leitmotif in Taylor (2007).

For Weber and other adherents of the secularisation thesis, it appeared that there was an inherent nexus between social modernisation and secularisation and that these processes necessarily follow a parallel and global path. This philosophical interpretation of history has been increasingly questioned since the 1990s - often under the label of postsecularism (Gabriel, 2008).

\section{Questioning secularisation and the debates on post-secularity}

For the mainstream in the social sciences in the second half of the 20th century, the secularisation thesis, in the sense of an irreversible loss of the significance of religion in presentday societies, was apparently an unquestioned consensus -

a kind of tacit knowledge (see "Contributed text 1"). To put it bluntly: important categories in the social sciences were class, the shift between capitalism and socialism, differences between north and south, and issues of race and gender, but neither culture nor religion were significant. To borrow Casanova's (2015:17) statement referenced earlier: many social scientists regarded life in a world without religion as normal.

However, if we take a closer look, the story of a complete domination of secular ideas in the social sciences and humanities turns out to be an illusion; in reality, this can be said only of certain academic milieus or disciplines. In fact, there were many internationally recognised and often quoted social scientists and philosophers, representing different intellectual movements, who made intensive investigations into the role of religions in society. These include Berger (1967), Luckmann (1967), Bourdieu (2011), Foucault (2014, orig. 1980), Luhmann (2000) in his posthumously published work Die Religion der Gesellschaft (English: A systems theory of religion), Ricœur (1995), or Galtung $(1980,1996)$ in his studies of the social effects of religious cosmologies. And within the sociology of religion, scholars made clear that the idea of a simple disappearance of religion was inadequate to describe social reality: "Of course, religion does not disappear: institutions survive, consciousness lingers, religious individuals and groups persist" (Wilson, 1982:155, cited in Wunder, 2005:80). And finally, cultural anthropology, for example, retained its fascination with the phenomenon of religion in its analysis of present-day non-Western societies. In the 1990s, in the course of the cultural turn, when cultural anthropology rose to become a kind of new leading discipline in the social sciences and humanities, studies in cultural anthropology relating to religion also attracted new interest in the neighbour- 
ing disciplines. ${ }^{5}$ However, the religion-related contributions of those authors did not have a broad reception. Nonetheless, the widespread narrative of the hegemony of the secularisation thesis should be relativised and treated with caution.

A reference point for the fundamental critique of the secularisation thesis in the 1990s was the study published in 1994 by José Casanova, Public religions in the modern world, which significantly influenced international debates on religion, politics, and modernity (Große Kracht, 2010:270). This study motivates the reader initially by referring to the attention paid since the 1980s to the topic of religion in the media (see Fig. 2), politics, and the social sciences based on the evidence of particular events and processes, such as

- the Iranian Revolution and the rise of supranational forms of Islamic extremism,

- the violent conflicts in the Balkans and in the Middle East, with their increasingly religious connotations, and the role played by Pope John Paul II in the peaceful revolution in eastern Europe,

- the social and political consequences of the growth and spread of Protestant free churches in the Americas,

- and, for example, the fact that Nancy Reagan, as America's First Lady, consulted astrologers in respect of political decisions made by her husband (Casanova, 1994:4).

Casanova interprets these phenomena as signs of a revitalisation of at least the public role of religion and thus as a kind of deprivatisation of religion, contrary to the mainstream idea of secularisation in the social sciences, and argues that it is necessary to revise common secularisation theories, at least in part (Casanova, 1994:5). In 1999, with the publication of the edited volume The desecularization of the world: resurgent religion and world politics, Peter Berger also prominently distanced himself from an unreflected acceptance of the theory of secularisation: "My point is that the assumption that we live in a secularized world is false. The world today, with some exceptions to which I will come presently, is as furiously religious as it ever was, and in some places more so than ever. This means that a whole body of literature by historians and social scientists loosely labelled 'secularization theory' is essentially mistaken” (Berger, 1999:2).

\footnotetext{
${ }^{5}$ With methodological essays like "Thick Description: Toward an Interpretive Theory of Culture" (Geertz, 1973b), cultural anthropologist Clifford Geertz, for instance, became a reference author for the cultural turn in the social sciences. In a large number of publications, he offered ethnographically based analyses of contemporary Islam (Geertz, 1971) or anthropological approaches to religion in general (Geertz, 1973a). It is remarkable, however, that the broad acceptance of his methodological ideas, not least in (new) cultural geography, did not lead to a deeper interest outside his own discipline in his substantial research on contemporary religion.
}

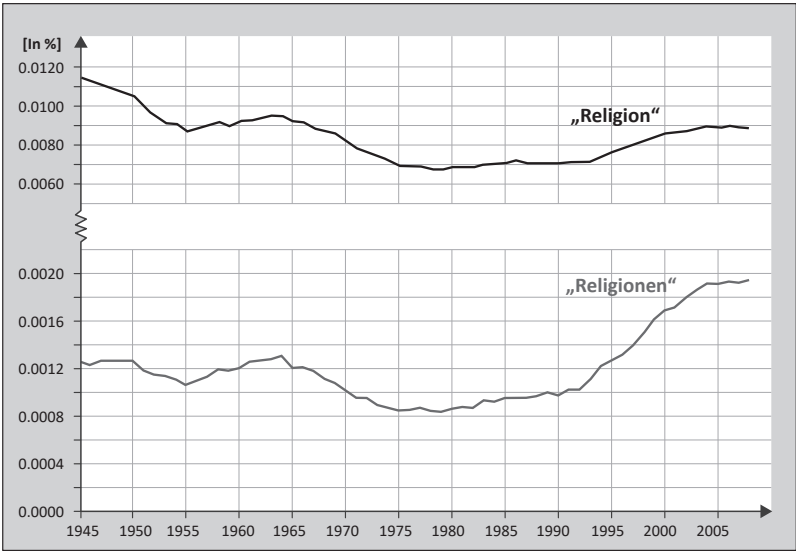

Figure 2. The relative frequency of German-language books in the Google book corpus relating to the word "Religion" and its plural form "Religionen" over time (1945-2008), as represented in the Google Ngram data. The graph seems to confirm the declining role of religion in publicistic debates from about 1963 to the end of the 1970s, in line with the secularization thesis, and a renewed interest in the subject of religion from about 1993. At the same time, it is clear that the phenomenon of religion is increasingly conceived of in the plural (second graph; note the different scales). However, due to the specific construction of the Google Ngram corpus (with changing selection criteria for the corpus over time), the reliability of the curves as indicators of cultural change is low (see Koplenig, 2017; Zhang, 2017), and they should be regarded as soft indications rather than as reliable proof.

The studies published by Talal Asad from the 1990s onwards question the theories of secularisation in an even more fundamental fashion. Asad argues that large parts of the secularisation debate are Eurocentric and that the categories secular and religious have been naturalised as a universal binary opposition (2003). The experience of secularisation as a social process has to be seen as a specific feature of modernisation in western European societies and is thus tied in various ways to the specific political and social situation of Christian churches in Europe. He points out that the political concept or ideology of the separation of state and religion - secularism - was born in western Europe and then exported to all parts of the world through colonisation (see also Iqtidar, 2012). Thus, he considers the categories of secular and religious as co-constitutive constructions with a specific background in European societies and in the European history of ideas. Authors such as Asad (1993a, b, 1999, 2003) and Iqtidar (2012) argue that the secular and the religious are not given and distinct social spheres but that they are contingent categories of modernity (in its many different forms), which are separated or mixed in very different ways and which mutually constitute each other. Thus, questions relating to how and by whom the secular and the religious are defined, delimited, kept separate, or allowed to overlap are always also questions about politics and the exercise of power. 
As Parmaksız (2018:99) has pointed out, the term postsecular emerged in the 1960s and 1970s in the context of social theologies and was centred around the question of how religious communities can adjust to a secular age on the one hand and overcome its pathologies on the other. However, these normatively driven theological debates at first found little resonance within the social sciences. It was not until the early 2000s that the term post-secular became a key component of discussions on the social role of religion. ${ }^{6}$ Interestingly, as many authors agree (see for instance Barbieri, 2015:59), it was Jürgen Habermas, a prominent theoretician of modernity, who catapulted the term post-secular into the central areas of academic and public debates. "For many people, Habermas' supposed turn towards religion was a sensation (literally 'drumbeat', German: Paukenschlag); he himself seemed to be the embodiment of the "post-secular society' of which he spoke" (Bochinger, unpublished data). As the most influential representative of the second critical theory generation, Habermas hardly mentioned issues relating to the sociology or philosophy of religion in his voluminous work up to the 1990s (see Reder and Schmidt, 2008:12). However, after his speech held on the occasion of being awarded the Peace Prize of the German Book Trade in October 2001, Habermas became one of the most sought-after speakers on topics relating to religion in contemporary societies. In his speech, entitled "Glauben und Wissen" (English: Faith and Knowledge), Habermas takes the attacks on the World Trade Center in New York, which had taken place just a few weeks earlier, as the starting point of his reflections and first describes contemporary religious fundamentalism as a phenomenon inside, not outside, modernity (Habermas, 2001:10). ${ }^{7}$ However, Habermas does not see the new visibility of religion as a purely negative phenomenon, as his choice of $9 / 11$ as a starting point for his arguments might suggest. For him, a post-secular society is one "which accepts the continued existence of religious communities in an increasingly secularised environment" (Habermas, 2001:13, translated from German) and which must learn to ensure that believers and unbelievers are able to carry on a public dialogue (p. 14). For this purpose, religious groups need to translate the religious content of their arguments into secular, or generally shared, terms, in the way that some Christian actors have started to do in ethical debates on genetic engineering, for example (Habermas, 2001:14, 20 pp.). Thus, while Casanova and Berger reject at least the basic tenet of the theories of secularisation, emphasising instead the continuing

\footnotetext{
${ }^{6}$ As shown by Beckford (2012), for example, scattered instances of the term post-secular can be found from the end of the 1960s. But a broad conceptional debate with a large number of conferences, edited volumes, and articles was launched only in the 2000s.

${ }^{7}$ In this text Habermas does not explain why he sees the attacks as part of modernity. In our opinion, the choice of a modern technical instrument such as an aeroplane to carry out an attack on a symbolically charged site is not adequate justification.
}

or growing importance of religion, Habermas preserves the notion of a largely secular public and political arena. Thus, Habermas uses the term post-secularity mainly to refer to a new perspective on religion within societies that are continuing to become further secularised (see also Habermas, 2008).

The prominent use of the term by Habermas triggered an intensive, interdisciplinary, and polyphonic post-secularity debate that still continues today. Within this debate, we can distinguish at least three aspects, or uses, of the term, which are quite distinct in different publications but often overlap: ${ }^{8}$ (1) post-secularity as the description of a new era where religion is of stable or increasing significance, (2) postsecularism as a normative programme demanding the acceptance of religious voices in the public sphere, and (3) postsecularity as a conceptual paradigm shift in the social sciences which denaturalises secularity.

1. The term post-secularity and its derivations like postsecular society, post-secular cities, or especially a post-secular age tend to suggest a stadial understanding: post-secularity as the historical era after a period of secularity. However, there are very few authors (e.g. Thomas, 2003) who explicitly use these terms in such a way and link them to a global resurgence of religion (a process whose empirical evidence remains disputed; see, for example, Moghadam, 2003; Graf, 2004; Krech, 2015). Habermas critically reflects on the argument of a resurgence of religion and argues in a nuanced way that the term post-secular society can be applied to European societies (and countries like Australia, Canada, and New Zealand), where a consciousness of living in secularised societies became common after World War II and where this consciousness now needs to adjust to the increased significance of religion, at least in the public sphere (2008).

2. The claim that modern societies increasingly rely on religious principles for ethical orientation has been linked by some authors to the notion of post-secularism (or post-secularity; for a summary, see for instance Barbieri, 2015:66). As Parmaksiz (2018) has shown, this understanding can be traced back to authors with backgrounds in Christian and Jewish (social) theology writing in the 1960s and 1970s. Later, in the context of the post-secularity debate, such a receptive attitude to the normative messages in religious texts can also be observed in the writings of other authors from philosophy and political theory (see for example Kristeva, 2009, and many articles in the edited book on political theologies by de Vries and Sullivan, 2006). Habermas (2005:137) describes "believers and religious communities" explicitly as "resources that create meaning" for the secular society. In an exchange with Joseph Ratzinger, Pope Benedict XVI, he reflects on the fa-

\footnotetext{
${ }^{8}$ Barbieri (2015) proposes a division into six aspects.
} 
mous Böckenförde dilemma and worries about a derailing secularisation that might lead to a running dry of the sources of societal solidarity (Habermas, 2007). ${ }^{9}$

3. A number of authors use the notion post-secularity to designate a paradigmatic shift that denaturalises secularity and thus makes it possible to analyse the contingencies, historicities, and geographies of secularity in a manner inspired by Foucauldian perspectives and often builds on the discussion by Asad of formations of the secular (see Oosterbaan, 2014; Barbieri, 2015; Gökarıksel and Secor, 2015; Molendijk, 2015; Fordahl, 2016; Parmaks1z, 2018). Such a shift enables a thematic opening of the social sciences and the humanities towards the always specific configurations of secularity and religion (see for example the discussion by Hancock (2008) on spatialities of the secular) and the relation of religion and secularity to questions of power, identity, and politics. ${ }^{10}$ What is more, such a decisively constructivist perspective, which challenges established concepts and boundaries, can also be helpful for a consideration of contemporary practices of spirituality and sacralisation beyond the big, established religious organisations (Bartolini et al., 2017; Schmitt, 2017) Of course research on new forms of religiosity is older than, and was developed independently from, the notion of post-secularity (e.g. Bochinger, unpublished data). But the reference to the concept might be used as a reminder that religion is not just a declining but, in the conditions of modernity, a vital phenomenon - and that its vitality is essentially driven by encounters between different religious traditions in the context of globalisation and by encounters between religious traditions and modernity.

The notion of post-secularity, and the wider post-secularity debate, has aroused criticism in religious studies and sociology of religion. In particular, many authors reject the idea of a post-secular era or period (aspect 1 above) which chronologically follows a secular period (e.g. Joas, 2004;

${ }^{9}$ In 1976, the German constitutional judge Ernst-Wolfgang Böckenförde said, "The liberal, secularised state depends on conditions which it cannot guarantee." (Orig.: "Der freiheitliche, säkularisierte Staat lebt von Voraussetzungen, die er selbst nicht garantieren kann"). See also the Benedikt Korf contributed text, below.

${ }^{10}$ The history of the "Sociology of Religion" section in the German Sociology Association (Deutsche Gesellschaft für Soziologie) reflects this opening: due to the dominance of the secularisation theory, this section was closed at the beginning of the 1970s and then re-opened in 1995 (DGS, 2017). The new academic interest in religion, which was in part politically inspired, found expression in the establishment of chairs and professorships in sociology of religion, as well as professorships in Islamic religious studies. Up to now there has been no comparable institutionalisation of such a disciplinary focus in university departments of geography in Germany.
Beckford, 2012; Krech, 2015; cf. the contributed text below by Bochinger, who prefers religious heterogeneity to postsecularity as a basic concept for the analysis of religion in contemporary societies). These authors argue that there has never been a definitely secular age and that there is no clearcut break leading to de-secularisation and a resurgence of religion; while it is true that the individual and social importance of religion has undergone fundamental changes in the modern period, the idea of an era of completely secularised societies is untenable. Even in western European societies, religious practices, religious organisations, or religiously legitimated discourses have never disappeared. And while many empirical observations suggest that the public and political importance of religion has been increasing since the end of the 20th century (see Fig. 2 or, for example, the disproportionately high number of publications in German on issues relating to religion), ${ }^{11}$ there is also empirical evidence of ongoing processes of secularisation, such as the continuing fall in numbers of church members in many western European societies (see for example Krech, 2015).

The understanding of post-secularity as a normative programme (aspect 2), as post-secularism, might be a valuable impulse for the different theologies and their exchange with philosophy and wider political theory. In an exchange with philosophical traditions related to the Enlightenment, religious arguments might occur as potential ethical resources. And these exchanges can help the social sciences to reflect on their own, often rather implicit, normative foundations and also on the implicit ethical foundations of contemporary societies. However, we would argue that the empirical social sciences are better equipped to observe and analyse these de-

\footnotetext{
${ }^{11}$ For example, in November 2015 numbers 2 to 5, 14 and 19 on the well-known Spiegel non-fiction bestseller list were books that were clearly devoted to religious issues. While number one on this list of non-fictional works was "The secret life of trees" (German: Das geheime Leben der Bäume), number two was "Incredulous amazement. On Christianity” (German: Ungläubiges Staunen. Über das Christentum) by Navid Kermani, a German-Iranian intellectual. Number 3 was "The fighter in the vatican" (German: Der Kämpfer im Vatikan), a portrait of Pope Francis by journalist Andreas Englisch, and number 4 was a critical biography of the Prophet entitled "Mohamed. A critical review" (German: Mohamed. Eine Abrechnung) by the German-Egyptian political scientist Hamed AbdelSamad. A thin volume entitled "Ethics is more important than religion" (German: Ethik ist wichtiger als Religion) containing an interview with the Dalai Lama by Franz Alt was number 5. Number 14 was a report by journalist Jürgen Todenhöfer entitled "Inside IS - 10 days inside the "Islamic State"' (German: Inside IS - 10 age im 'Islamischen Staat'), and number 19 was "Mecca Germany. The silent Islamisation" (German: Mekka Deutschland. Die stille Islamisierung) by the clearly anti-Islamic journalist Udo Ulfkotte. Other titles in this list were devoted to philosophy, including a history of philosophy entitled "Know the world" (German: Erkenne die Welt) by Richard David Precht, or could be described as philosophical or psychological self-help books (e.g. Wilhelm Schmid's "Serenity", German: Gelassenheit).
} 
bates than to participate in them. The social sciences should critically analyse these debates as social and political negotiations inevitably shaped by questions of power.

An understanding of post-secularity which overcomes universalist and teleological conceptions of a globally progressive secularisation (aspect 3 ) is helpful for analysing and understanding the contingent social processes that produce specific configurations of religious and non-religious beings in the world in specific social, historical, and geographical contexts (see the articles in Burchardt et al., 2015). However, there are also authors who warn the social sciences that there is only a thin line between such a denaturalisation of secularity and religion and a cultural relativism which would impede any critique. Thus, in a discussion of post-secular feminism, Vasilaki (2016) acknowledges these writings for enabling a critique of excluding and marginalising practices legitimised as secular while at the same time criticising them for losing sight of the marginalisation and exclusion produced by some religious practices and subjectivities (see also the discussion in Özdemir Sönmez, 2010, on the end of a secular Ankara or the critical review of Asad's Genealogies of religion by Lincoln, 1995).

In Table 1, we offer a comparison of contemporary secular, post-secular, and neo-fundamentalist religious perspectives and their translation into physico-material geographies and topographies. We relate the post-secular perspectives to the three different understandings of post-secularity developed in this chapter, which, however, often overlap in respect of specific phenomena or arguments. This is an indicator of the empirical coherence of the debates on post-secularity. The table also shows that it is possible to link different post-secular perspectives either to secular or to neo-fundamentalist religious positions, inasmuch as the sense of an argument is boosted or weakened in one or the other direction. Adequate approaches in the social sciences, as we see in post-secularity aspect 3 (PS 3), normally avoid binary black or white thinking.

\section{Contributed text 1: religious heterogeneity as an} alternative to post-secularity (Christoph Bochinger, Bayreuth)

The concept of the post-secular, at least in the German-speaking countries, entered public discourses in 2001 following Jürgen Habermas' speech entitled "Faith and Knowledge", made on the occasion of being awarded the Peace Prize of the German Book Trade. For many people, Habermas' supposed turn towards religion was a sensation; he himself seemed to be the embodiment of the post-secular society of which he spoke. The speech was made in the autumn of 2001, shortly after the spectacular events of 11 September. At the beginning of his speech, Habermas describes the situation as an "apocalyptic" confrontation between the secular and religious worlds.
He then discusses the dialectics of secularisation, which even in the so-called West has led to fundamentalism and apparently irreconcilable religious and non-religious positionings within one and the same society. Seen from the perspective of the study of religion, we may note that Habermas, like Charles Taylor, does not present empirically based arguments in the strict sense but describes and interprets certain intellectual, epistemological, and political or ethical developments in normative terms. At least Habermas is fully aware of this. Despite their references to spectacular events in the present, these two authors do not defend the thesis of a shift away from secularisation and back to religion in the traditional sense. Yet this thesis is frequently linked to the concept of post-secularity. As we often hear, secularisation was a dominant paradigm in the academic discourse from the first half of the 20th century and to a certain extent still is today. This paradigm dominated not only those disciplines that were devoted to religion, especially sociology of religion, but also many other disciplines. Thus, for a long time it was taken for granted in the mainstream of political science and international relations to assume that religion is unimportant in modern political processes. Current developments in religion and politics have led to such disciplines revising their ideas so that now they talk of a resurgence of religion. This is not primarily a matter of whether religion is on the increase or the decrease in the world as a whole; the point is that these disciplines have discovered that they must take religion into account, although they define themselves as secular sciences. This is a problem that scholars in religious studies (and I presume also scholars interested in religion and geography) may not be able to appreciate, because for them it is clear that they need to distinguish between their own location in the secular world of science and scholarship and the religious location of the phenomena they set out to study. Much more fundamental than criticism based on empirical findings is the post-colonial critique of the secularisation paradigm going back mainly to two books published by the anthropologist Talal Asad: Genealogies of religion (Asad, 1993b) and Formations of the secular (Asad, 2003). This critique has mainly influenced those areas of religious studies that deal with non-Western societies but is also more wide-reaching. Asad (1993b) regards the binary religious-secular as a specific construction of Western modernity, which was spread around the world in the course of colonialism and postcolonialism. From this point of view, it is difficult 
Table 1. Secular and secularist, post-secular, and neo-fundamentalist positions and perspectives - a comparison.

\begin{tabular}{|c|c|c|c|}
\hline & $\begin{array}{l}\text { Secularist and secular } \\
\text { perspectives }\end{array}$ & Post-secular perspectives & $\begin{array}{l}\text { Religious neo- } \\
\text { fundamentalist } \\
\text { perspectives }\end{array}$ \\
\hline $\begin{array}{l}\text { As scientific } \\
\text { programmes }\end{array}$ & $\begin{array}{l}\text { (a) Historically: } \\
\text { emancipation of } \\
\text { empirical sciences } \\
\text { from religious } \\
\text { institutions and } \\
\text { theology } \\
\text { (b) Assumption that } \\
\text { religion is to a great } \\
\text { extent irrelevant for } \\
\text { explaining the } \\
\text { contemporary } \\
\text { (social) world; } \\
\text { religion as a declining } \\
\text { relict of premodern } \\
\text { societies }\end{array}$ & $\begin{array}{l}\text { Recognition of the } \\
\text { relevance of religious } \\
\text { phenomena in the social } \\
\text { sciences (and humanities) } \\
\text { (PS } 3 \text { and 1)* } \\
\text { Analysis of the co- } \\
\text { constitution and the } \\
\text { delimitation of religious } \\
\text { and secular spheres } \\
\text { (PS 3) } \\
\text { Religion as a normative } \\
\text { source - also for the } \\
\text { social sciences (PS 2) } \\
\text { Assumption of a renewed } \\
\text { significance of religion in } \\
\text { societies (PS } 1 \text { and - } \\
\text { normatively - PS 2) }\end{array}$ & $\begin{array}{l}\text { Contestation of scientific } \\
\text { theories which are seen } \\
\text { as contradictory to } \\
\text { religious doctrines (e.g. } \\
\text { the theory of evolution } \\
\text { by US evangelicals) }\end{array}$ \\
\hline $\begin{array}{l}\text { Conception of relation } \\
\text { between state and } \\
\text { religions }\end{array}$ & $\begin{array}{l}\text { Weak form: } \\
\text { independence of states } \\
\text { or governmental } \\
\text { institutions from religion; } \\
\text { separation of } \\
\text { governmental and } \\
\text { religious institutions } \\
\text { Strong form: opposition } \\
\text { to religion in the public } \\
\text { sphere }\end{array}$ & $\begin{array}{l}\text { Recognition of the } \\
\text { importance of religious } \\
\text { institutions and voices in } \\
\text { the public sphere (esp. } \\
\text { PS 2) }\end{array}$ & $\begin{array}{l}\text { Reversal of secular } \\
\text { political structures (e.g. } \\
\text { Turkey after 2016) }\end{array}$ \\
\hline $\begin{array}{l}\text { Normative positions in } \\
\text { respect of religion in the } \\
\text { public sphere }\end{array}$ & $\begin{array}{l}\text { Weak: limitation of role } \\
\text { of religion and its truth } \\
\text { claims in public } \\
\text { discourse; emergence of } \\
\text { non-religiously grounded } \\
\text { or atheist truth claims } \\
\text { Strong (explicit or } \\
\text { hidden): assertion of } \\
\text { religiously grounded } \\
\text { arguments in public } \\
\text { discourses }\end{array}$ & $\begin{array}{l}\text { Recognition or } \\
\text { acceptance of the } \\
\text { legitimacy of religiously } \\
\text { founded arguments and } \\
\text { religious voices in a } \\
\text { pluralist society (esp. } \\
\text { PS 2) }\end{array}$ & $\begin{array}{l}\text { Delegitimation of secular } \\
\text { or atheist arguments } \\
\text { within the public sphere } \\
\text { (e.g. Islamic countries } \\
\text { referring to an Islamic } \\
\text { law; campaign by } \\
\text { Christian creationists in } \\
\text { the USA against the } \\
\text { teaching of the theory of } \\
\text { evolution in public } \\
\text { schools) }\end{array}$ \\
\hline
\end{tabular}


Table 1. Continued.

\begin{tabular}{|c|c|c|c|}
\hline & $\begin{array}{l}\text { Secularist/secular } \\
\text { perspectives }\end{array}$ & Post-secular perspectives & $\begin{array}{l}\text { Religious neo- } \\
\text { fundamentalist } \\
\text { perspectives }\end{array}$ \\
\hline \multicolumn{4}{|l|}{ Empirical phenomena } \\
\hline \multirow[t]{4}{*}{$\begin{array}{l}\text { Institutionalisation of } \\
\text { religions within societies }\end{array}$} & $\begin{array}{l}\text { Diminishing influence of } \\
\text { religion due to functional } \\
\text { differentiation of } \\
\text { societies }\end{array}$ & $\begin{array}{l}\text { Ongoing relevance of } \\
\text { religious institutions } \\
\text { within societies }\end{array}$ & $\begin{array}{l}\text { Roll-back of religious } \\
\text { institutions (e.g. Turkey } \\
\text { since 2016) }\end{array}$ \\
\hline & & $\begin{array}{l}\text { Renaissance of religious } \\
\text { institutions and religious } \\
\text { practices after an era of } \\
\text { secularisation (PS 1) }\end{array}$ & \\
\hline & & $\begin{array}{l}\text { New ritual and } \\
\text { organisational formats } \\
\text { within established } \\
\text { Christian churches (e.g. } \\
\text { city churches) (PS 3) }\end{array}$ & \\
\hline & & $\begin{array}{l}\text { Historically and } \\
\text { geographically contingent } \\
\text { constitutions of specific } \\
\text { secularities and religions } \\
\text { (PS 3) }\end{array}$ & \\
\hline \multirow[t]{2}{*}{$\begin{array}{l}\text { Physico-material } \\
\text { geographies and } \\
\text { topographies }\end{array}$} & $\begin{array}{l}\text { In Europe: } \\
\text { demolition of } \\
\text { superfluous churches } \\
\text { or new use for profane } \\
\text { purposes }\end{array}$ & $\begin{array}{l}\text { Multireligious } \\
\text { appearance of urban } \\
\text { neighbourhoods with } \\
\text { facilities for different } \\
\text { religious communities } \\
\text { (PS } 1 \text { and 3) }\end{array}$ & $\begin{array}{l}\text { Destruction of religious } \\
\text { buildings belonging to } \\
\text { communities whose } \\
\text { beliefs are seen as } \\
\text { contradictory to own } \\
\text { religious beliefs (e.g. by } \\
\text { Islamist groups in North }\end{array}$ \\
\hline & & $\begin{array}{l}\text { Reuse of religious } \\
\text { buildings for new } \\
\text { religious purposes }\end{array}$ & Africa and Middle East) \\
\hline \multirow[t]{2}{*}{$\begin{array}{l}\text { Individual practices and } \\
\text { beliefs }\end{array}$} & $\begin{array}{l}\text { In Europe: } \\
\text { decline in numbers of } \\
\text { - church members } \\
\text { - people with religious } \\
\text { beliefs } \\
\text { - individual religious } \\
\text { practices (such as } \\
\text { participation in } \\
\text { religious services) } \\
\text { - people regarding } \\
\text { observance of } \\
\text { religious practices as } \\
\text { binding }\end{array}$ & $\begin{array}{l}\text { Religious decline as a } \\
\text { mainly European } \\
\text { phenomenon (and in } \\
\text { formerly socialist } \\
\text { countries); not so in } \\
\text { other parts of the world } \\
\text { (possible interpretation } \\
\text { according to PS 3) } \\
\text { Revitalisation of religious } \\
\text { practices in Europe due } \\
\text { to immigration (PS } 1 \text { and 3) }\end{array}$ & $\begin{array}{l}\text { Global spread of } \\
\text { universal fundamentalist } \\
\text { (not locally grounded) } \\
\text { variants of religious } \\
\text { norms, with strict beliefs } \\
\text { and strict observance of } \\
\text { religious norms (such as } \\
\text { Salafism) }\end{array}$ \\
\hline & & $\begin{array}{l}\text { Popularisation of Asian } \\
\text { forms of religious } \\
\text { practice in Europe and } \\
\text { Western countries } \\
\text { (yoga, Buddhist } \\
\text { meditation) (PS 3) }\end{array}$ & \\
\hline
\end{tabular}

* PS: post-secularity. The arguments in the rightmost column are assigned to the three different understandings of post-secularity as developed in Sect. 3. 
to speak of post-secular societies because this is still based on the binary religious-secular.

Although events in many present-day globalised societies can certainly be described as post-secular, I think it is less misleading to speak of religious heterogeneity. Like many other societies, German society is characterised neither by complete secularisation nor by the opposite but by increasing heterogeneity. While the great majority of people in Germany attach little importance to religion, there are people for whom it is important or who suddenly find it important. Religion can dominate all aspects of a person's life, even if other people find this hard to understand. Despite all efforts to initiate interreligious dialogue and understanding, religion is, at least potentially, a stumbling block that is not comprehensible to outsiders. People who have no interest in religion are generally not interested in interreligious dialogue and see no point in such activities. It is also characteristic of many religious groupings that they refuse to talk to people with different ideas. I think that as scholars interested in the study of religion or in religion and geography, we need to reveal this heterogeneity and not cover it up in the name of an interreligious ideal.

This text is a translation from the German, based on excerpts from the keynote address "Religiös heterogene Gesellschaften. Die Debatte um Postsäkularismus aus religionswissenschaftlicher Perspektive", delivered on 11 June 2015 in Erlangen by Christoph Bochinger at the conference entitled "Geographien post-säkularer Gesellschaften".

Christoph Bochinger holds the chair for the Study of Religion with a special focus on contemporary culture at the University of Bayreuth. From 2009 to 2017 he was chairman of the German Association for the Study of Religions (Deutsche Vereinigung für Religionswissenschaft).

\section{The debate on (post-)secularity within social and cultural geography - past receptions and future potentials for research}

The theories of secularisation have not received much explicit attention in social and cultural geography. The mainstream of the discipline during the second half of the 20th century seems to have implicitly conceived of religion as being obsolete and of little social significance.

However, since the 1990s, religion has aroused new interest in social and cultural geography (see for example Kong,
2010; Dwyer, 2016). Not least as a result of the new importance of religion in public discourses (see above), geographers have carried out research on the role of religion in processes of identity construction, identity politics, and political confrontations (see, for example, Schmitt, 2003, on conflicts over the building of mosques in Germany; Hopkins, 2007, on the role of religion in the construction of identity among adolescents in Great Britain; Reuber, 2015, on "political geographies of the religious" in Tibet; or Hancock, 2015, on the headscarf debate in France).

Before this backdrop, a discussion in geography of the secularisation theory (see Wunder, 2005:234; Wilford, 2010; Tse, 2014) and the post-secularity debate has begun. On the one hand, this discussion draws on the interdisciplinary discussions initiated by Habermas. On the other hand - and this may well irritate some social scientists - it also draws on genuinely theological and ethical debates (cf. Parmaks1z, 2018). A group of British geographers forged a link between the post-secularity debate and empirical studies carried out in western European cities, with a focus on social services provided by organisations which define themselves as religious ("faith-based organisations", especially Christian organisations) and on the ethical and normative motives of these actors and organisations. Thus, Cloke et al. (2005) discuss to what extent organisations that provide services for homeless people on the street in Great Britain are motivated not only by a religious, Christian caritas or a secular humanist logic but also by a post-secular ethic which does not follow universal ideas of right and wrong but which determines what is ethically right in each particular context (p. 309). In later articles (e.g. Cloke, 2011), Cloke develops the concept of theo-ethics, which he regards as a discursive shift within Western Christianity, away from a missionary agenda and towards caritas (in the sense of practical charity) and agape (in the sense of altruistic love). Beaumont (2008) discusses the effects of neo-liberalism on the welfare state in the Netherlands and shows how faith-based organisations fill the gaps left by cutbacks in state services - often based on collaboration between religiously and non-religiously motivated volunteers. In later articles, Cloke and Beaumont (2013) describe this form of collaboration as "post-secular rapprochement". Williams (2015) builds on the work of Cloke and Beaumont (2013) and, in an empirical study of a homeless centre run by the Salvation Army in the UK, shows how the practical translation of theo-ethics can intersect with humanistically motivated practices and be opposed to the neoliberal and libertarian logics of social services. This reception of the post-secularity debate stresses the ethical potentials of religion and can thus be interpreted as an element within a broad turn to questions of ethics and morality within social and cultural geography.

However, some scholars engaged in the field of religion and geography have been more cautious in their reception of the post-secularity debate. In particular, Kong (2010) criticises ideas of post-secularity as a re-emergence or re- 
engagement of spirituality, ethics, and/or the sacred as being historically oversimplified and too Eurocentric. Like Ley (2011), she criticises the implicit or explicit discourse of newness. They both reject the idea of secular and post-secular eras or periods (see also Benedikt Korf's critique of the postsecularity debate in "Contributed text 2"). Wunder (2005) and Wilford (2010) have made a more fundamental criticism: these two geographers claim that social and cultural geography should deal much more intensively with the theories of secularisation and criticise the post-secularity debate as being too superficial and too normative to serve as the basis for an adequate discussion of religion in the social sciences. On the basis of a well-informed discussion of the theories of secularisation, and a fairly broad definition of religion, they argue that processes of social differentiation have led to fundamental changes in the conditions for religion in the modern age and that the resulting transformation processes can be adequately described in terms of the theories of secularisation. They both interpret the increasing religious diversity in the US as the result of processes of differentiation under secular conditions. Ultimately, they argue that the theories of secularisation must be clearly distinguished from normative political programmes of secularism and that the task of social and cultural geography should be to investigate the different spatial and contextual transformation paths followed by religion in the modern age (see Cannell, 2010, for similar arguments in respect of anthropology). A problematic aspect, however, is their narrow conception of (Western) modernity. In the case of Wunder, this leads to an explicit spatial limitation of his interpretations to Europe and North America (see also the review by Henkel, 2006), and in the case of Wilford, despite claims that his arguments have global validity, the empirical examples he uses to illustrate them are (almost) exclusively from North America.

In recent years, there has been a broader conceptual debate on post-secularity as a denaturalisation of secularity and religion within social and cultural geography. Thus, Gökarıksel and Secor (2015) follow an understanding of post-secularity which refers to the genealogical and de-essentialising view of the secular proposed by Asad (2003). In their study of everyday experiences of headscarf-wearing women in Istanbul, they show how the borders between the religious and the secular are constantly negotiated and disputed. Gökarıksel and Secor (2015) give up the idea of a supposedly neutral, secular public sphere (a concept retained by Habermas, for example) and adopt instead the idea commonly found in debates in social and cultural geography, namely, that the material and symbolic form of public spaces, and the normative expectations associated with encounters in public spaces, are socially constructed and pervaded by power. Thus, conceptions of a secular public space need to be analysed as specific political constructions. In a similar way, O’Mahony (2018), in his analysis of Marian statues in Dublin, connects local practices of place-making with religion, secularity, identities, and geopolitical events on different scales. Gao et al. (2018) analyse the "hybrid and contradictory" processes of secularisation and religious revival in so-called gospel villages with many rural migrant workers in the Shenzhen area. They use a post-secular perspective to analyse the overlapping and parallel geographies of processes of secularisation and resacralisation.

\section{Contributed text 2: provincialising the concept of the} secular (Benedikt Korf, Zurich)

Until recently, most (critical, leftist) geographers seem to have been "religiously unmusical": consciously or unconsciously, they imagined religion as something out of place in their studies and their radical or progressive politics (Henkel, 2011). Implicit in these imaginations has been a teleological Enlightenment thinking that placed secularism at the endpoint of history, both as a state of a society and as a way of thought. This teleological thinking falls prey to what Doreen Massey has called "turning geography into history", i.e. placing different configurations across space along a normative, teleological axis of stages in an evolutionary progress. The concept of post-secularism questions the idea of this secular endpoint, but it does not solve Massey's (2006) concern about the turning of geography into history, for the debates on postsecularism have been Eurocentric and teleological - they had to be, in fact. The very idea of postsecularism presupposes that there has been something approximating a secular society from which a post-secular society has now evolved through the advent of a new religious revival. Such a view is questionable at best (Joas, 2004:123) and sounds awkward to people living at the post-colonial margins far away from the universe of enlightened Western intellectuals.

It is the task of cultural and political geography, therefore, to contribute to the project of provincialising the idea, politics, and practice of (post-)secularism. Talal Asad (2003) started to provincialise the concept of the secular genealogically: how this concept is tied to particular ideas of Enlightenment that had their origin in Europe and then travelled to other sites. Asad provided the groundwork for a number of complementary practices to provincialise the idea of secularism that geographers need to embrace. In a first step, we should zoom in to disentangle the geographies in this genealogy by acknowledging the multiple genealogical sites where a variety of ideas of (post-)secularism have been debated within the Western tradition. For example, we cannot fully grasp Habermas' Friedenspreis speech without acknowledging the canonic status that the 
famous dictum of former German constitutional judge Ernst-Wolfgang Böckenförde enjoys in German public and academic debates on the role of religion in society and politics. Böckenförde wrote that "Der freiheitliche, säkularisierte Staat lebt von Voraussetzungen, die er selbst nicht garantieren kann" (Böckenförde, 1976:60) (The liberal secularised state lives by prerequisites which it cannot guarantee itself). Böckenförde's dictum seems to imply that a secular, liberal democracy needed to be rejuvenated by the moral resources of religion(s), a position that Habermas embraced in his concept of post-secularism. The influence of this dictum resonates with the wide-spread entanglements of the Christian churches with the secular state in Germany, which would be incompatible, for example, with the French idea of laïcité.

In a second step, we should zoom out to look beyond the Western tradition, i.e. at how the idea of secularism has travelled to other sites and been rearranged and reshaped in the process of acculturation. Today, almost all societies live through some form of religious pluralism: "Religious pluralism is the normal condition in which religious subjectivities are formed" (Das, 2014:82); this includes agnostic and atheist positions (Quack, 2012). Secularism is not only the separation of politics from religion in the singular but from many religions with different theologies, institutions, and traditions. India, a society with a secular constitution and a multitude of spiritually strong religions, has had to experiment with this difficult task, and although religious violence has emerged regularly in recent decades largely as a result of the rise of Hindu nationalism, Indian intellectuals have been at pains to conceptualise a model of Indian secularism (R. Barghava). Perhaps those ideas could fruitfully inform European deliberations about how to deal with Islam and other non-Christian religions in a secular democracy.

In a third step, geographers need to provincialise the concept of the secular ethnographically, showing how - in everyday practices, religion, and politics - the religious and the secular are multiply entangled, and yet there are many attempts to purify these concepts to claim boundaries between these realms. In this sense, geographers should observe these concepts as categories of practice (R. Brubaker), i.e. observe how these categories and the boundaries between them are negotiated, translated, purified, and rearranged in different social or political configurations. A number of recent ethnographic studies on the everyday politics of religion in post-war, post-colonial societies have been concerned with political struggles over the proper place of religious actors in public life and politics. In her study of Catholic priests in Sri Lanka's civil war, Deborah Johnson (2015), for example, has shown how religious actors became highly political but could do so only by claiming a religious exceptionality that made them untouchable to the violent political actors surrounding them. Observing deliberations between civil rights activists and Islamic leaders in post-war and post-tsunami Aceh, Christine Schenk has probed into the politics of textual interpretations to reconcile secular concepts of women's rights with the ethical injunctions of Islam in law-making processes (Schenk, 2018). Philippa Williams has studied how Muslims in India invoke the "rhetoric of secularism" to propagate their citizenship rights and to undergird their political belonging to the Indian state (Williams, 2012).

All these ethnographies of the everyday entanglements of religion and politics force us to unravel the idea of post-secularism, if post is to be understood as a period coming after and going beyond a period of secular society. Paraphrasing Bruno Latour, we might come to the conclusion that "we have never been secular" (and never will be).

Let us now summarise the relevance of the debate on post-secularity for social and cultural geography and conversely possible contributions from geography to this interdisciplinary debate. We would argue that social and cultural geography can benefit from a broader reception of the (post-)secularity debate. A denaturalisation of secularity and religion helps to sensitise geographers to the relevance, the specific roles, the delimitation, and the co-constitution of practices and arguments legitimised and framed as religious or secular in contemporary societies (see aspect 3: postsecularity as a paradigmatic shift). At the same time, such a decisively constructivist perspective also enables a broad conception of religion which goes far beyond the practices of European Christianity or the classical world religions.

Having said that, we need to consider the possible contributions of social and cultural geography to the interdisciplinary debates on (post-)secularity. We would argue that social and cultural geography is well equipped for studying the role of specific spatial configurations for the constitution and stabilisation of specific social relations. Research in social and cultural geography can analyse how practices which are legitimised as religious or secular interact, or are disputed, in the symbolic and material production processes of (public) spaces. Such research can link the debates on post-secularity explicitly with approaches related to the material turn in the social sciences and humanities, which was to a large extent inspired by geographers (Hicks, 2010) and has already had an 
influence on interdisciplinary research on religion (Karstein and Schmidt-Lux, 2017). Studies informed by the material turn take materialities, objects, and artefacts as a starting point for cultural studies (in contrast to the hitherto dominating philological practices within religious studies). The combination of approaches inspired by the material turn and debates on (post-)secularity allows us to reflect on how materialities and material arrangements in religious fields express, symbolise, and structure changed relations between religious traditions and the state, the changed situation of religions in the public sphere, and encounters between religion and modernity and between different religious traditions. Duttweiler (2017), for example, looked into the materiality of new multireligious spaces and Schmitt (2017) into that of new spiritual centres connected with both Christian and Buddhist traditions. Last but not least, the tradition of regional comparison in geography might contribute in overcoming universalistic conceptions and thus be part of an agenda aiming at " "provincialising' the idea, politics and practices of (post-)secularism" (see Korf in "Contributed text 2"). However, such a research agenda, aiming at the understanding of geographies of religion and secularity and sometimes labelled as a "spatial turn in religious studies"(for example, by Dwyer, 2016), must be based on a sound knowledge of theological systems and debates, as well as on the history of specific traditions and translations of secularity, and thus requires interdisciplinary cooperation.

\section{Conclusion and outlook}

The secularisation thesis, which was widely accepted as an unquestioned background consensus in the social sciences in the second half of the 20th century, has given way since the 1990s to a polyphonic debate - often under the label of post-secularity. The question of the role of religion in contemporary societies, and, not least, of the relationship between identity, politics, and religion in different contexts in different parts of the world, has gained new importance. However, critical voices have pointed out that the arguments put forward by those who regard the post-secular as a return of the religious, as well as by those who conceive of the post-secular as an ideal interaction between religious and non-religious actors within a public, secular, and democratic arena, are extremely Eurocentric.

Nevertheless, the post-secularity debate has led to discussions in the social sciences on the role of religion and on the production, delimitation, and contingency of the secular and the religious. As we see it, social and cultural geography can profit from such a conceptional sensibilisation. The reception of the concept in social and cultural geography has already given some initial impulses for such an opening. However, the debate is not free of the above-mentioned Eurocentrism. A profounder discussion of the contingent nature of secularity and the combination of such a perspective with approaches from social and cultural geography is therefore required. This includes studying the role of practices which regard themselves as religious or secular in the symbolic and material production of (public) spaces or investigating specific regional paths in respect of the delimitation and coconstitution of secularity and religion.

The empirical studies presented in this special issue, which go back to a conference and a panel session in 2015 (see footnote 2), represent attempts to explore the benefits of using these approaches to the empirical analysis of contemporary societies, in the border zone between social and cultural geography, religious studies, sociology of religion, and, for instance, architecture.

Data availability. The data used in this paper is available upon request by contacting the correspondence author.

Author contributions. The article was jointly developed and written by the authors, with approximately equal shares regarding the substantial contents and the workload during the production process.

Competing interests. The authors declare that they have no conflict of interest.

Edited by: Benedikt Korf

Reviewed by: three anonymous referees

\section{References}

Asad, T.: The construction of religion as an anthropological category, in: Genealogies of Religion: Discipline and Reasons of Power in Christianity and Islam, edited by: Asad, T., The Johns Hopkins University Press, Baltimore, London, 1993a.

Asad, T.: Genealogies of Religion: Discipline and Reasons of Power in Christianity and Islam, The Johns Hopkins University Press, Baltimore, London, 1993b.

Asad, T.: Religion, Nation-State, Secularism, in: Nation and religion: Perspectives on Europe and Asia, edited by: van der Veer, P. and Lehmann, H., Princeton Univ. Press, Princeton, NJ, 178196, 1999.

Asad, T.: Formations of the secular: Christianity, Islam, modernity, Stanford Univ. Press, Stanford, California, 269 pp., 2003.

Barbieri, W. A.: Sechs Facetten der Postsäkularität, in: Postsäkularismus: Zur Diskussion eines umstrittenen Normative Orders, 12, Begriffs, edited by: Lutz-Bachmann, M., Campus-Verl., Frankfurt am Main, 41-78, 2015.

Bartolini, N., Chris, R., MacKian, S., and Pile, S.: The place of spirit, Prog. Human Geogr., 41, 338-354, 2017.

Beaumont, J.: Faith Action on Urban Social Issues, Urban Stud., 45, 2019-2034, https://doi.org/10.1177/0042098008094871, 2008.

Beckford, J. A.: Public Religions and the Postsecular: Critical Reflections, J. Sci. Stud. Relig., 51, 1-19, 2012. 
Berger, P. L.: The Sacred Canopy: Elements of a Sociological Theory of Religion, Doubleday \& Company, Inc., Garden City, New York, 1967.

Berger, P. L.: The Desecularization of the World: A Global Overview, in: The desecularization of the world: Resurgent Religion and World Politics, Ethics and Public Policy Center, Washington, D.C., 1-18, 1999.

Bochinger, C.: New Age und moderne Religion - Religionswissenschaftliche Analysen, Gütersloher Verlagshaus, Gütersloh, 1994.

Böckenförde, E.-W.: Die Entstehung des Staates als Vorgang der Säkularisation, in: Staat, Gesellschaft, Freiheit: Studien zur Staatstheorie und zum Verfassungsrecht, Suhrkamp, Frankfurt am Main, 42-64, 1976.

Bourdieu, P.: Religion: Schriften zur Kultursoziologie, Suhrkamp, Berlin, 278 pp., 2011.

Burchardt, M., Wohlrab-Sahr, M., and Middell, M. (Eds.): Multiple secularities beyond the West: Religion and modernity in the global age, Religion and its others, 1, de Gruyter, Berlin, Boston, 317 pp., 2015.

Cannell, F.: The Anthropology of Secularism, Annu. Rev. Anthropol., 39, 85-100, https://doi.org/10.1146/annurev.anthro.012809.105039, 2010.

Casanova, J.: Public Religions in the Modern World, The University of Chicago Press, Chicago, London, 1994.

Casanova, J.: Die Erschließung des Postsäkularen: Drei Bedeutungen von "säkular" und deren mögliche Transzendenz, in: Postsäkularismus: Zur Diskussion eines umstrittenen Begriffs, Normative Orders, 12, 1st Edn., edited by: Lutz-Bachmann, M., Campus-Verl., Frankfurt am Main, 9-40, 2015.

Cloke, P.: Emerging geographies of evil? Theo-ethics and postsecular possibilities, Cult. Geogr., 18, 475-493, https://doi.org/10.1177/1474474011401993, 2011.

Cloke, P. and Beaumont, J.: Geographies of postsecular rapprochement in the city1, Prog. Human Geogr., 37, 27-51, https://doi.org/10.1177/0309132512440208, 2013.

Cloke, P., Johnsen, S., and May, J.: Exploring Ethos? Discourses of 'Charity' in the Provision of Emergency Services for Homeless People, Environ. Plan A, 37, 385-402, https://doi.org/10.1068/a36189, 2005.

Das, V.: Cohabiting an inter-religious milieu: reflections on religious diversity, in: A Companion to the Anthropology of Religion, edited by: Boddy, J. and Lambek, M., Wiley Blackwell Companions to Anthropology, Wiley, Hoboken, 69-84, 2014.

De Vries, H. and Sullivan, L. E. (Eds.): Political Theologies: Public Religions in a Post-Secular World, Fordham University Press, New York, 800 pp., 2006.

DGS: Sektion Religionssoziologie, http://www.soziologie.de/de/ sektionen/sektionen/religionssoziologie/startseite.html, last access: 22 February 2017.

Duttweiler, S.: Grenzarbeit zwischen Sakralisierung und Profanität. Multireligiöse Räume in nicht-religiösen Kontexten, in: Architekturen und Artefakte: Zur Materialität des Religiösen, edited by: Karstein, U. and Schmidt-Lux, T., Veröffentlichungen der Sektion Religionssoziologie der Deutschen Gesellschaft für Soziologie, Springer VS, Wiesbaden, 193-211, 2017.

Dwyer, C.: Why does religion matter for cultural geographers?, Social Cult. Geogr., 17, 758-762, 2016.
Fordahl, C.: The post-secular: Paradigm shift or provocation?, Eur. J. Soc. Theory, 20, 550-568, https://doi.org/10.1177/1368431016645821, 2016.

Foucault, M.: Die Regierung der Lebenden: Vorlesung am Collège de France 1979-1980, orig. 1980, 1st Edn., Suhrkamp, Berlin, 495 pp., 2014.

Gabriel, K.: Jenseits von Säkularisierung und Wiederkehr der Götter, Aus Politik und Zeitgeschichte, 2008, 9-15, 2008.

Galtung, J.: Sivilisasjon, kosmologi, fred og utvikling, in: Det norske vitenskapsakademi, Universitetsvorlaget Oslo, Oslo, 130-153, 1980.

Galtung, J.: Peace by peaceful means: Peace and conflict, development and civilization, Sage, Los Angeles, 280 pp., 1996.

Gao, Q., Qian, J., and Yuan, Z.: Multi-scaled secularization or postsecular present? Christianity and migrant workers in Shenzhen, China, Cult. Geogr., 25, 553-570, 2018.

Geertz, C.: Islam Observed: Religious Development in Morocco and Indonesia, The University of Chicago Press, Chicago, London, 1971.

Geertz, C. (Ed.): The interpretation of cultures: Selected essays by Clifford Geertz, Basic Books, Inc., New York, 1973a.

Geertz, C. (Ed.): Thick Description: Toward an interpretive theory of culture, in: The interpretation of cultures: Selected essays by Clifford Geertz, Basic Books, Inc., New York, 3-30, 1973 b.

Gökarkksel, B. and Secor, A.: Post-secular geographies and the problem of pluralism: Religion and everyday life in Istanbul, Turkey, Polit. Geogr., 46, 21-30, https://doi.org/10.1016/j.polgeo.2014.10.006, 2015.

Graf, F. W.: Die Wiederkehr der Götter. Religion in der modernen Kultur, Beck, München, 2004.

Große Kracht, H.-J.: Einführung, in: Religion und Gesellschaft, Texte zur Religionssoziologie, edited by: Gabriel, K. and Kracht, H.-J. G., Schöningh, Paderborn, 2010.

Habermas, J.: Glauben und Wissen, in: Glauben und Wissen: Friedenspreis des Deutschen Buchhandels 2001, edited by: Habermas, J. and Reemtsma, J. P., Suhrkamp, Frankfurt, 9-31, 2001.

Habermas, J.: Religion in der Öffentlichkeit. Kognitive Voraussetzungen für den "öffentlichen Vernunftgebrauch" religiöser und säkularer Bürger, in: (id., Ed.): Zwischen Naturalismus und Religion, Suhrkamp, Frankfurt, 119-154, 2005.

Habermas, J.: Vorpolitische Grundlagen des demokratischen Rechtsstaates, in: Dialektik der Säkularisierung. Über Vernunft und Religion, edited by: Ratzinger, J., Herder, Freiburg im Breisgau, S. 15-38, 2007.

Habermas, J.: Die Dialektik der Säkularisierung, in: Blätter für deutsche und internationale Politik, Blätter Verlagsgesellschaft mbH, Berlin, 1-13, 2008.

Hancock, C.: Spatialities of the Secular, Eur. J. Women. Stud., 15, 165-179, 2008.

Hancock, C.: 'The Republic is lived with an uncovered face' (and a skirt). (un)dressing French citizens, Gender Place Cult., 22, 1023-1040, 2015.

Henkel, R.: Review on: Wunder, E.: Religion in der postkonfessionellen Gesellschaft, Die Erde, 2006, 51-52, 2006.

Henkel, R.: Are geographers religiously unmusical? Positionalities in geographical research on religion, Erdkunde, 65, 389-400, 2011. 
Hicks, D.: The material-cultural turn: Event and effect, in: The Oxford handbook of material culture studies, edited by: Hicks, D. and Beaudry, M. C., Oxford Univ. Press, Oxford, 20-98, 2010.

Hopkins, P. E.: Young people, masculinities, religion and race: new social geographies, Prog. Human Geogr., 31, 163-177, 2007.

Iqtidar, H.: Secularism and Secularisation.: Untying the Knots, Econ. Polit. Weekly, XLVII, 50-58, 2012.

Joas, H.: Braucht der Mensch Religion?: Über Erfahrungen der Selbsttranszendenz, Herder, Freiburg, 192 pp., 2004.

Johnson, D.: Taking liberties and making liberty: Religious bounding and political violence in Sri Lanka, Religion, 46, 309-330, https://doi.org/10.1080/0048721X.2016.1139012, 2015.

Karstein, U. and Schmidt-Lux, T. (Eds.): Architekturen und Artefakte: Zur Materialität des Religiösen, Veröffentlichungen der Sektion Religionssoziologie der Deutschen Gesellschaft für Soziologie, Springer Fachmedien, Wiesbaden, 303 pp., 2017.

Kong, L.: Global shifts, theoretical shifts: Changing geographies of religion, Prog. Human Geogr., 34, 755-776, https://doi.org/10.1177/0309132510362602, 2010.

Koplenig, A.: Why the quantitative analysis of diachronic corpora that does not consider the temporal aspect of time-series can lead to wrong conclusions, Digit. Scholar. Human., 32, 159-168, https://doi.org/10.1093/llc/fqv030, 2017.

Krech, V.: Wiederkehr der Religion? Und nach welcher Säkularisierung? Beobachtungen zur religiösen Lage im 20. und zu Beginn des 21. Jahrhunderts, in: Postsäkularismus: Zur Diskussion eines umstrittenen Begriffs, edited by: Lutz-Bachmann, M., Campus-Verl., Frankfurt am Main, 259-289, 2015.

Kristeva, J.: This Incredible Need to Believe, Columbia University Press, New York, 136 pp., 2009.

Ley, D.: Preface: Towards the postsecular city?, in: Postsecular cities: Space, theory and practice, edited by: Beaumont, J. and Baker, C., Continuum resources in religion and political culture, London, xii-xiv, 2011

Lincoln, B.: Book Review: Genealogies of Religion: Discipline and Reasons of Power in Christianity and Islam by Talal Asad, Hist. Relig., 35, 83-86, 1995.

Luckmann, T.: The Invisible Religion: The Transformation of Symbols in Industrial Society, Macmillan, New York, 128 pp., 1967.

Luhmann, N.: Die Religion der Gesellschaft, Suhrkamp, Frankfurt am Main, 361 pp., 2000

Mahne-Bieder, J. and Hilpert, M.: Religiöse Diversität in der (post-)modernen deutschen Gesellschaft, in: Handbuch Diversity Kompetenz: Gegenstandsbereiche, edited by: Genkova, P. and Ringeisen, T., Springer Fachmedien, Wiesbaden, 1-16, 2016.

Massey, D.: Space, time and political responsibility in the midst of global inequality, Erdkunde, 60, 89-95, 2006.

Moghadam, A.: A global resurgence of religion?, Working paper series/Weatherhead center for International Affairs 03/03, WCFIA, Cambridge, Massachussets, 2003.

Molendijk, A. L.: In pursuit of the postsecular, Int. J. Philos. Theol., 76, 100-115, https://doi.org/10.1080/21692327.2015.1053403, 2015.

Müller, H.-P.: Max Weber: Eine Einführung in sein Werk, 1st Edn., UTB Soziologie, Böhlau, Cologne, 311 pp., 2007.

O'Mahony, E.: Connecting the local and the global in post-secular urban settings, Geogr. Rev., 52, 1-24, 2018.

Oosterbaan, M.: Public religion and urban space in Europe, Social Cult. Geogr., 15, 591-602, 2014.
Özdemir Sönmez, N.: The End of the Secular City Dream - The Case of Ankara, in: Exploring the postsecular. The religious, the political and the urban - International studies in religion and society 13, edited by: Molendijk, A. L., Jedan, C., und Beaumont, J., E. J. Brill, Leiden, Boston, 243-265, 2010.

Parmaksız, U.: Making sense of the postsecular, Eur. J. Soc. Theory, 21, 98-116, https://doi.org/10.1177/1368431016682743, 2018.

Pickel, G.: Religionssoziologie: Eine Einführung in zentrale Themenbereiche, VS Verlag für Sozialwissenschaften, Springer Fachmedien Wiesbaden GmbH, Wiesbaden, 2011.

Quack, J.: Disenchanting India: Organized Rationalism and Criticism of Religion in India, Oxford University Press, New York, 380 pp., 2012.

Reder, M. and Schmidt, J.: Habermas und die Religion, in: Ein Bewußtsein von dem, was fehlt: Eine Diskussion mit Jürgen Habermas, edited by: Habermas, J. and Reder, M., Suhrkamp, Frankfurt am Main, 9-25, 2008.

Reuber, P.: Politische Geographien des Religiösen - Ambivalenzen der Verkopplung von Religion und Raum im Fall Tibet, Geogr. Helv., 70, 109-119, https://doi.org/10.5194/gh-70-1092015, 2015.

Ricœur, P.: Figuring the sacred: Religion, narrative, and imagination, Fortress Press, Minneapolis, Minn., 340 pp., 1995.

Schenk, C.: Islamic leaders and the legal geography of family law in Aceh, Indonesia, Geogr. J., 184, 8-18, 2018.

Schmitt, T. M.: Moscheen in Deutschland: Konflikte um ihre Errichtung und Nutzung, Forschungen zur Deutschen Landeskunde, Deutsche Akademie für Landeskunde, Selbstverlag, Flensburg, 382 pp., 2003.

Schmitt, T. M.: UNESCO as Red Cross or as a notary of World Heritage: Structures, scale-related interactions and efficacy of UNESCO's World Heritage regime, MMG working papers, MMG, Göttingen, 2015.

Schmitt, T. M.: Neue spirituelle Zentren - Manifestationen und Materialisationen kreativer religiöser Synthesen? Das Beispiel des Benediktushofs in Unterfranken, in: Architekturen und Artefakte: Zur Materialität des Religiösen, Veröffentlichungen der Sektion Religionssoziologie der Deutschen Gesellschaft für Soziologie, edited by: Karstein, U. and Schmidt-Lux, T. Springer Fachmedien Wiesbaden, Wiesbaden, 163-189, 2017.

Taylor, C.: A secular age, Belknap Press of Harvard University Press, Cambridge, Mass., 874 pp., 2007.

Thomas, S. M.: Taking religious and cultural pluralism seriously. The global resurgence of religion and the transformation of international society, Millennium: J. Int. Stud., 29, 815-841, 2003.

Tse, J. K.: Grounded theologies: 'Religion' and the 'secular' in human geography, Prog. Human Geogr., 38, 201-220, 2014.

Vasilaki, R.: The Politics of Postsecular Feminism, Theory Cult. Soc., 33, 103-123, 2016.

Weber, M.: Die Stadt. Eine soziologische Untersuchung, Archiv für Sozialwissenschaft und Sozialpolitik, 47, 621-772, 1920.

Weber, M.: Gesammelte Aufsätze zur Religionssoziologie I, orig. 1920, 9th Edn., Uni-Taschenbücher Religionswissenschaft, 1488, Mohr, Tübingen, 573 pp., 1988.

Wilford, J.: Sacred archipelagos: geographies of secularization, Prog. Human Geogr., 34, 328-348, https://doi.org/10.1177/0309132509348558, 2010.

Williams, A.: Postsecular geographies: theo-ethics, rapprochement and neoliberal governance in a faith-based 
drug programme, Trans. Inst. Brit. Geogr., 40, 192-208, https://doi.org/10.1111/tran.12069, 2015.

Williams, P.: India's Muslims, lived secularism and realising citizenship, Citizenship Stud., 16, 979-995, 2012.

Wunder, E.: Religion in der postkonfessionellen Gesellschaft: Ein Beitrag zur sozialwissenschaftlichen Theorieentwicklung in der Religionsgeographie, in: Sozialgeographische Bibliothek, 5, Franz Steiner, Stuttgart, 366 pp., 2005.
Zhang, S.: The Pitfalls of Using Google Ngram to Study Language, https://www.wired.com/2015/10/ pitfalls-of-studying-language-with-google-ngram/, last access: 21 September 2017. 